\title{
総合論文*
}

\section{反応熱によるプローブ光の偏向を利用する 新規化学計測法}

\author{
尅 行 正 $^{* *}$
}

\section{A novel chemical measurement method based on reaction heat-induced optical beam deflection}

\author{
Xing-Zheng $\mathrm{Wu}^{* *}$ \\ ** Department of Industrial Chemistry, Faculty of Technology, Tokyo Metropolitan University, \\ 1-1, Minami Ohsawa, Hachioji-shi, Tokyo 192-03
}

(Received 13 September 1995)

The principle, instrumentation, and applications of a novel chemical measurement method based on reaction heat-induced optical beam deflection (OBD) have been discussed in detail. A theoretical equation that describes reaction heat-induced OBD for a very fast reaction (impulse reaction) is first derived by considering the thermal diffusion process. For a slow chemical reaction, its reaction heat-induced OBD signal is treated with the concept of convolution. The neutralization reaction is used as a model fast reaction for verification of the derived theoretical equation and investigation of the basic experimental conditions. It has been demonstrated that the magnitude of reaction heatinduced OBD is proportional to the amount of reactant, and the reaction rate can be deduced by analyzing the time decay curve of the reaction heat-induced OBD signal. Applications of the method to redox reaction and enzyme reaction systems have also been investigated. Furthermore, real time one dimensional imaging detection for reaction heat-induced OBD is also demonstrated. Further development and applications of the method are also discussed.

Keywords : reaction heat-induced optical beam deflection; neutralization reaction; redox reaction; enzyme reaction; reaction rate; one dimensional imaging.

\section{1 序 論}

生化学, 反応化学等の分野で, 化学反応過程にできる だけ外から刺激を与えず，その場でありのままで化学種 を測定する in-situ 計測法への要望がますます強くなっ てきた．現在使用されている化学反応過程の計測法には

* 関東支部創立 40 周年記念

** 東京都立大学工学部工業化学科: 192-03 東京都八王 子市南大沢 1-1
大きく分けると，反応物あるいは生成物の性質の変化を 測定する手法と, 反応過程で放出された反応エネルギー を測定する手法とがある．前者には吸光分光法などの各 種分光法 ${ }^{1) 2)}$ が, 後者には熱量測定法 (カロリメト リー $)^{3) 4)}$, 化学発光分析法 ${ }^{5) 6)}$, アコースティックエミ ション分析法 ${ }^{7 / 8)}$ が代表的な手法としてある.これらの 方法の中で熱の測定に基づく分析法はすべての反応系に 適用できる. 従来からはん用されている熱量測定分析法 では, 試料とサーミスターを温度制御された密閉容器内 
に置き測定を行う7)8). 最近, 醉素を熱電対の表面に直 接固定し, センサー形式で酵素反応熱を直接測定する研 究も行われている ${ }^{9)}$. この測定方式は測定環境の温度制 御を必要としないので, 従来の熱量測定法より優れたも のとして注目されている.

一方, 光熱変換分光法でプローブ光の偏向を利用する ビーム偏向測定法は, 光を吸収した分子の無放射緩和過 程で放出される微弱な熱でも測定できる高感度な熱測定 法であり, 光熱変換分光法の分野ではよく知られてい $3^{(0)}$ - 16). 又, ビーム偏向測定法は電極表面, 膜/溶液 界面での物質の拡散過程で生じた濃度こう配 ${ }^{17) ~ 22) ~ 及 ひ ゙ ~}$ 密度こう配 ${ }^{23)}$ の高感度測定にも使用されている.この ビーム偏向測定法は非接触, 非侵襲, in-situ, 遠隔測定 が可能などの特長を持つ.

化学反応過程ではエンタルピー変化あるいは反応熱が 発生する．著者らはこの反応熱に着目した．すなわち， 化学反応熱により, 反応媒質及びその周辺に温度こう配 を生じ, この温度こう配が屈折率こう配を誘起する. 更 に誘起された屈折率こう配が反応場周辺を通過するプ ローブ光を偏向させる．そこで，プローブ光の偏向を測 定, 解析することにより, 反応物あるいは生成物の定量 分析を行え, 更に反応速度などの動的挙動に関する知見 が得られると考えられる. 著者らはこの発想に基づい て, 化学反応熱によるビーム偏向効果を利用する新規 $i n$-situ 計測法を提案し, 更にその応用研究も行ってき $た^{24 \sim 30)}$. この反応熱によるビーム偏向法は, 光熱変換 分光法でのビーム偏向法及び濃度こう配によるビーム偏 向法之は原理的に異なるもので, 又測定対象, 応用範囲 も異なり, 従来の手法にない独自の特幑を持つ.ここで は, 本手法の理論, 実験方法及び応用について述べる.

\section{2 理 論}

Fig. 1, A に示すように, 水及び水と混合しない溶媒 をセルに設置し（溶媒の密度が水より小さい場合, 水が 下で溶媒が上である), 化学反応を水相で発生させ, プ ローブ光が界面付近の溶媒相を通過する系を考える，座 標軸については, Fig. 1, A に示したように水相と溶媒 相界面の法線を $z$ 軸の方向とし, 又水/溶媒界面を原点 とする.

まず，水相反応の反応熱により誘起した溶媒相での温 度こう配を検討する．この場合, 化学反応熱が唯一一の熱 源と仮定する。

\section{$\mathbf{2} \cdot \mathbf{1}$ 瞬間的な反応の場合}

水相では, ある反応 $\mathrm{A}+\mathrm{B} \longrightarrow \mathrm{C}$ の反応速度が熱拡散

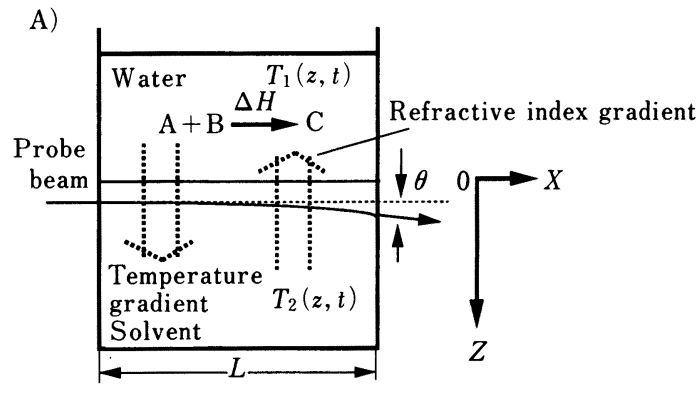

B)

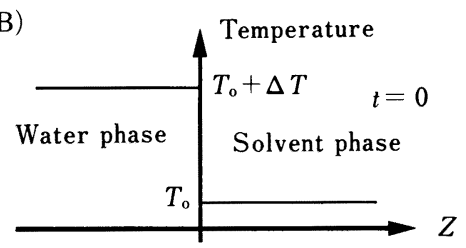

Distance from water/solvent interface

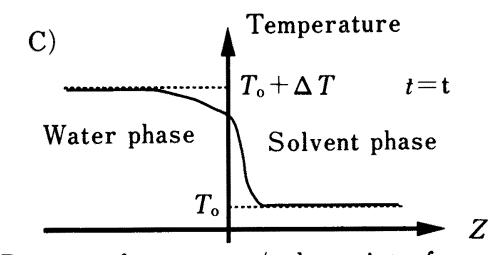

Distance from water/solvent interface

Fig. 1 Illustration of the principle of reaction heatinduced beam deflection (A), and temperature distribution at $t=0(\mathrm{~B})$ and $t=\mathrm{t}(\mathrm{C})$

に比較してはるかに速く，反応熱が瞬間的に発生すると 仮定する.つまり熱源としてはデル夕関数として取り扱 うことができるとする．この熱源により，水相では温度 が初期温度 $T_{0}$ から $T_{0}+\Delta T$ に上昇する (Fig. 1, B)。

$$
\Delta T=(\Delta H M) /\left(C_{1} M_{1}\right)
$$

式 (1)で $\Delta H, M, C_{1}$ 及び $M_{1}$ はそれぞれモル化学反 応熱 $(\mathrm{J} / \mathrm{mol})$, 反応物のモル量 $(\mathrm{mol})$, 水相の重量比 熱 $\left\{\mathrm{J} /\left(\mathrm{g}{ }^{\circ} \mathrm{C}\right)\right\}$, 及び水相の重量 $(\mathrm{g})$ である.

このデル夕関数として取り扱える熱源から発生した熱 の一部分は溶媒相に伝わる. その結果, Fig. 1, C に示 すように水/溶媒界面付近で溶媒相の温度が上昇する. 水/溶媒界面の熱拡散過程がそれぞれ次のような熱拡散 方程式に従う(ここでは， $\Delta T$ が小さく，熱伝導過程が 熱拡散のみと仮定する).

$$
k_{1} \frac{\partial^{2}}{\partial z^{2}} T_{1 \delta}(z, t)=\frac{\partial}{\partial t} T_{1 \delta}(z, t)
$$




$$
k_{2} \frac{\partial^{2}}{\partial z^{2}} T_{2 \delta}(z, t)=\frac{\partial}{\partial t} T_{2 \delta}(z, t)
$$

式 $(2)$ では, $T_{1 \delta}(z, t)$ と $T_{2 \delta}(z, t)$ はそれぞれ水相と 有機相の座標 $z$, 時刻 $t$ での温度で, $k_{1}, k_{2}$ はそれぞれ 水と溶媒の熱拡散係数 (単位: $\mathrm{m}^{2} / \mathrm{s}$ ) である. 熱拡散係 数は次のような式で熱伝導率 $K\left\{\mathrm{~J} /\left(\mathrm{m}^{\circ} \mathrm{C} \mathrm{s}\right)\right\}$, 重量比熱 $C\left\{\mathrm{~J} /\left(\mathrm{g}{ }^{\circ} \mathrm{C}\right)\right\}$, 及び密度 $\rho\left(\mathrm{g} / \mathrm{m}^{3}\right)$ から計算できる ${ }^{31)}$.

$$
k_{\mathrm{i}}=K_{i} C_{\mathrm{i}}^{-1} \rho_{\mathrm{i}}^{-1}(i=1,2)
$$

式 ( 2 ) で示された熱拡散方程式は次の式 (4)で示す境界 条件及び式 $(5)$ で示す初期条件のもので解ける.

$$
\left.\begin{array}{l}
T_{1 \delta}(z, t)=T_{2 \delta}(z, t) \\
K_{1} \frac{\partial}{\partial z} T_{1 \delta}(z, t)=K_{2} \frac{\partial}{\partial z} T_{2 \delta}(z, t)
\end{array}\right\} z=0
$$

その結果, 溶媒相での温度 $T_{2 \delta}(z, t)$ は次のようであ る.

$$
T_{2 \delta}(z, t)=T_{0}+\frac{K_{1} k_{1}^{1 / 2}}{K_{1} k_{1}^{1 / 2}+K_{2} k_{2}^{1 / 2}} \Delta T\left[1-\operatorname{erf}\left(\frac{z^{2}}{4 k_{2} t}\right)\right]
$$

又, 式 ( 6 ) から溶媒相での温度こう配 $\partial T_{2 \delta} / \partial z$ も次の ように求められる.

$$
\partial T_{2 \delta} / \partial z=\frac{K_{1} k_{1}{ }^{1 / 2}}{K_{1} k_{1}^{1 / 2}+K_{2} k_{2}^{1 / 2}} \frac{\Delta T}{2 \sqrt{\pi k_{2} t}} \exp \left(\frac{z^{2}}{4 k_{2} t}\right)
$$

一方, プローブビームの大きさがある温度こう配 $\mathrm{d} T / \mathrm{d} z$ の存在範囲よりはるかに小さいとき, その $\mathrm{d} T / \mathrm{d} z$ により誘起されるプローブ光の偏向角度 $\Delta \theta$ (Fig. 1, A) は次のようである ${ }^{10) 11)}$.

$$
\Delta \theta=\frac{L}{n} \frac{\mathrm{d} n}{\mathrm{~d} T} \frac{\mathrm{d} T}{\mathrm{~d} z}
$$

式 ( 8 ) 中の $L, n, \mathrm{~d} n / \mathrm{d} T$ はそれぞれプローブ光の温度 こう配での光路長, 溶媒の屈折率, 屈折率の温度依存係 数である. 式 $(7)$ を式 ( 8 )に代入すると, 式 ( 9$)$ が得ら れる.

$$
\Delta \theta=A \Delta H \frac{M}{M_{1}} \frac{\exp \left(-z^{2} / 4 k_{2} t\right)}{2 \sqrt{k_{2}} t}
$$

式 (9) 中の $A$ は定数であり, その值は溶媒相の光学的, 熱的な性質を表すパラメーターで，次の式で計算でき る.

$$
A=\frac{0.5(L / n)(\mathrm{d} n / \mathrm{d} T)\left(1 / C_{1}\right)}{1+\left(K_{2} / K_{1}\right)^{1 / 2}\left(C_{/} C_{1}\right)^{1 / 2}\left(\rho_{2} / \rho_{1}\right)^{1 / 2}}
$$

式 (9) は瞬間的に発生する化学反応の反応熱によるプ ローブ光の偏向信号を表している.

\section{$2 \cdot 2$ 遅い反応の場合}

上述したように，反応速度が非常に速くて，つまり熱 源としてはデル夕関数で取り扱えるような反応系の偏向 信号 $\Delta \theta$ は式 ( 9 )で表される.この $\Delta \theta$ は数学的にはイ ンパルス応答あるいは装置応答関数とも呼ふ332) 35).

反応速度が遅い場合, つまり熱源としてはデル夕関数 で取り扱えない反応系の偏向信号は, コンボリューショ

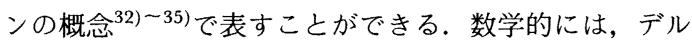
夕関数で取り扱えない熱源から生じた偏向信号は, その 熱の発生速度（反応速度に等しい）とインパルス応答と のコンボリューショ.ンになる28).つまり次のような式 で表される.

$$
\begin{aligned}
\Delta \Theta & =B \int_{0}^{t} R(\tau) \Delta \theta(t-\tau) \mathrm{d} \tau \\
& =\int_{0}^{t} R^{\prime}(\tau) \Delta \theta(t-\tau) \mathrm{d} \tau
\end{aligned}
$$

式 (11)中の $\Delta \Theta$ は熱源としてデル夕関数で扱えない遅 い反応の偏向信号で, $R(t)$ は熱源発生速度, つまり反 応速度である. 又, $B$ は遅い反応及び速い反応の反応熱 之関連する係数で, $R^{\prime}(t)$ は反応速度に比例するもの で, 次のような式で表される.

$$
R^{\prime}(t)=B R(t)
$$

$$
3 \text { 実験 }
$$

\section{3・1 測定系}

まず，測定系について説明する．測定系は Fig. 2, A に示すようである．基本的にはプローブ光の光源，反応 セル及び偏向測定系から構成される. プローブ光の光源

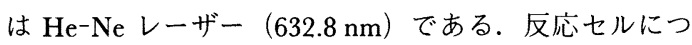
いては，バッチ法では市販の吸光光度分析用のセル (Fig. 2, A) 及びガラス管 $(4 \mathrm{~mm}$, o.d., $2.3 \mathrm{~mm}$, i.d.) の一端を薄い金ぱく（厚さ $10 \mu \mathrm{m}$ ) で封じたセルを用い た.フローインジェクション分析用のフローセルについ ては，薄い金ぱくで一端を封じたガラス管に送液用テフ ロンチューブを差し入れたものを用いた。偏向測定系に 
A)

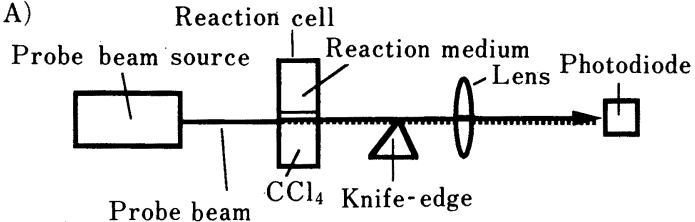

B)

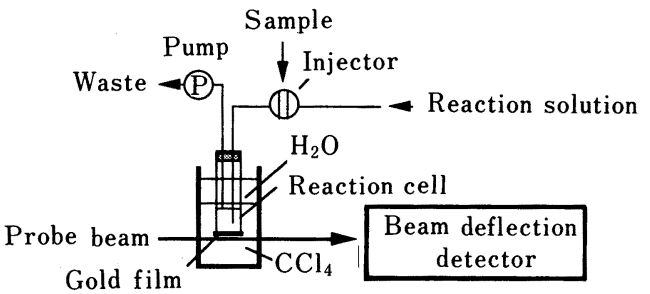

Fig. 2 Illustration of the experimental setup for reaction heat-induced beam deflection

A) : batch experiment; B): flow injection experiment

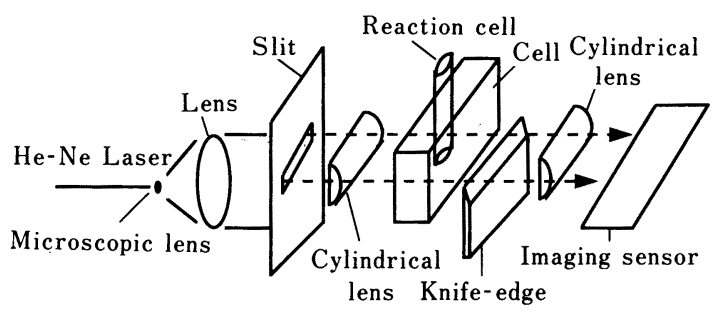

Fig. 3 Illustration of the experimental setup for one-dimensional reaction heat-induced beam deflection imaging

ついては，ナイフエッジとフォトダイオードから構成し た. プローブ光の半分をナイフエッジによりブロック し, 残った半分の光量をフォトダイオードでモニターし た。

化学反応熱による偏向信号の一次元測定系: Fig. 3 に 示すように，まずプローブ光を顕微鏡用レンズ及び焦点 距離が $10 \mathrm{~cm}$ の光学レンズにより広げた ${ }^{35)}$. 次に広げ たプローブ光の中心部分が幅 $0.5 \mathrm{~mm}$ のスリットを通 し，ガラス管から構成したセルの下の四塩化炭素相にあ てた. 反応セルの後部のプローブ光と平行なナイフエッ ジにより，プローブ光の半分をブロックした．ブロック されていないプローブ光の強度を一次元イメージセン サーによりモニターした.

\section{$3 \cdot 2$ 実験方法}

バッチ法では, あらかじめセルの下部分に四塩化炭素 相を入れ，その上に一方の反応物溶液を一定量入れてお き，次にマイクロシリンジでもう一方の反応物溶液を一 定量注入し, 化学反応させた.

フロー法では，フローセルにペリスタポンプで片方の 反応物溶液を導入し，もう一方の反応物をインジェク ターで流路に $20 \mu \mathrm{l}$ 注入した.

金ぱく上でのカタラーゼの固定化: カタラーゼはグル タルアルデヒドにより血清アルブミンと架橋した ${ }^{93) 36)}$. $10 \mathrm{mg}$ カタラーゼ及び $10 \mathrm{mg}$ 血清アルブミンを蒸留水 に溶かし，次にその溶液に $10 \mu \mathrm{l} 30 \%$ グルタルアルデ ヒド水溶液を加えた．得られた溶液を $80 \mu \mathrm{l}$ でガラス管 セルに加え，窒素雾囲気下で静置する．1 時間後金ぱく の上に厚さ約 $20 \mu \mathrm{m}$ の酵素膜が形成された.

\section{4 結果と考察}

\section{$4 \cdot 1$ 反応熱によるビーム偏向信号の測定及び基硙的 な検討}

反応熱により生じた偏向信号は反応媒質あるいはその 周辺の温度こう配 $\mathrm{d} T / \mathrm{d} z$ に比例するので, 原理的には, プローブ光を反応場内に直接通過させれば最大偏向信号 を得るはずである。しかし，この場合，反応場で反応物 の混合により生じた不安定，しかも複雑な密度変化によ り, 不安定な屈折率変化を生じるため, 反応熱による偏 向信号は正確に測定できない。 そこで，プローブ光を Fig. 2, A に示すように $\mathrm{CGl}_{4}$ 相に通し，その上に設置 した水相中で反応を起こさせる測定方式を考案した ${ }^{24)}$.

Fig. 4 に $\mathrm{CCl}_{4}$ 相の上に設置した $2 \mathrm{M} \mathrm{HCl}$ 溶液に 2 $\mathrm{M} \mathrm{HCl}, \mathrm{H}_{2} \mathrm{O}, 0.5 \mathrm{M} \mathrm{NaOH}$ 溶液をそれぞれ $50 \mu \mathrm{l}$ 滴 下したとき得た信号を示した. $\mathrm{HCl}$ 又は $\mathrm{H}_{2} \mathrm{O}$ を滴下し たとき, プローブ光の偏向信号は生じなかったが, $\mathrm{NaOH}$ 溶液を滴下したとき, フォトダイオードで検出 したプローブ光の光量ははじめに減少し，ある時間後滴 下する前のレベルに戻る. 中和反応は発熱反応であり, その反応熱が $\mathrm{CCl}_{4}$ 相に伝わり，Fig. 1, A に示したよ うな温度こう配, 屈折率こう配を誘起する。この屈折率 こう配により，プローブ光が $\mathrm{CGl}_{4}$ 側に曲がる. 従っ て，ナイフエッジによりブロックされたプローブ光の光 量が増え, フォトダイオードで検出される光量が小さく なる. 又, 時間がたつと温度こう配がなくなり，プロー ブ光が元の通過方向に戻り, 偏向信号がなくなる.

中和反応が速い反応（拡散律速）なのでここでは瞬 間的な反応と近似する。一方，理論部分で述べたよう に，瞬間的な反応の反応熱によるプローブ光の偏向信号 


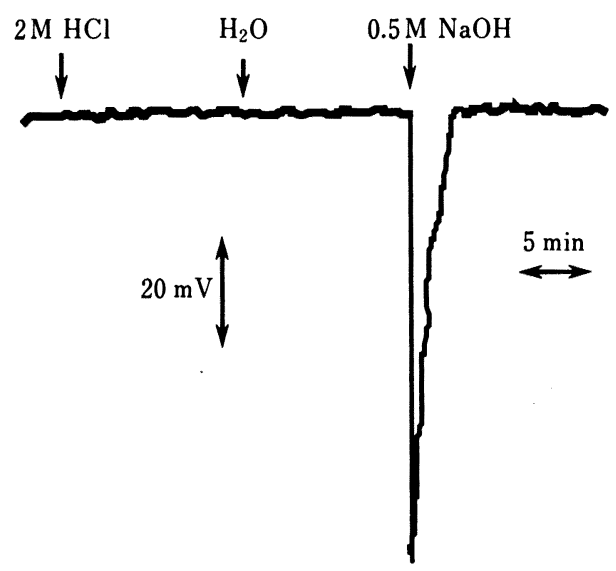

Fig. 4 Typical reaction heat-induced beam deflection signal for neutralization reaction

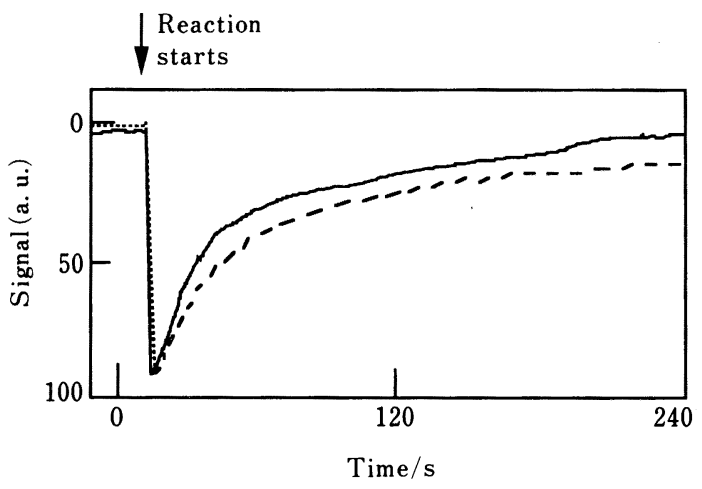

Fig. 5 Comparison of experimental beam deflection signal with the theoretical one

Solid line and dashed line represent experimental and calculated deflection signal, respectively.

が式 ( 9 )で記述できる.Fig. 5 では, 式 ( 9 )で計算した プローブ光の偏向信号及び実測データを示す．全体とし て，偏向信号の実測データが計算值と大体一致してい る. 計算値より実験値のほうが速く減衰したのは, 理論 モデルで一次元の熱拡散しか考えていなく, 又水相が無 限に長いと仮定したからである. 実際の熱拡散が三次元 拡散で, 又水相から空気相へ熱も拡散するので, 一次元 の拡散モデルより速く熱が散逸する.

一方, 実際の分析, 特に定量分析では, 信号のピーク 高さがよく用いられる. 反応熱による偏向信号がいつ最 大になるかについては, 式 $(9)$ を時間 $t$ で偏微分して 0

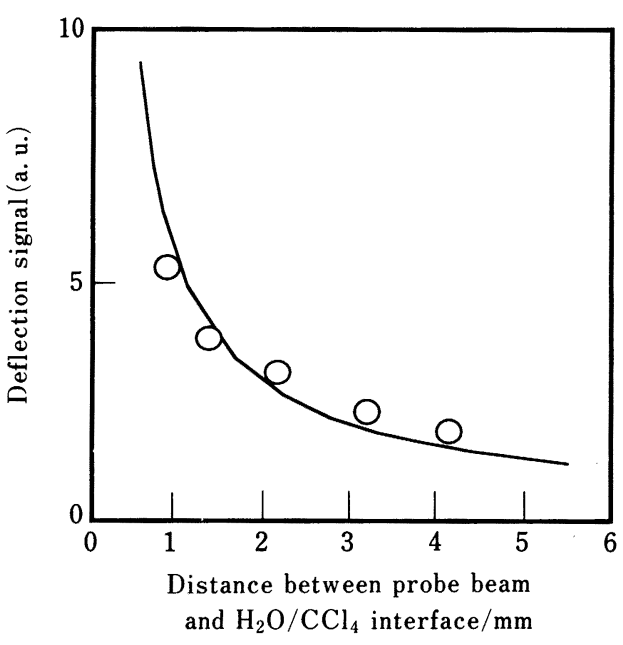

Fig. 6 Dependence of the reaction heat-induced beam deflection signal on the distance between the probe beam and $\mathrm{H}_{2} \mathrm{O} / \mathrm{CCl}_{4}$ interface

Solid line and circles are calculated and experimental results, respectively.

と置くこと $(\partial \Delta \theta / \partial t=0)$ により得られる. その結果， 偏向信号が最大になる時間 $t_{\max }$ は次のようになる.

$$
t_{\max }=z^{2} / 2 k_{2}
$$

式(13) 中の $z$ はプローブ光の通過位置で, プローブ光 と水 $/ \mathrm{CCl}_{4}$ 界面との距離を表す. 式 (13)を式 $(9)$ に代 入すれば, 最大偏向信号 $\Delta \theta_{\max }$, つまり偏向信号の ピーク高さは次のようになる.

$$
\Delta \theta_{\max }=\sqrt{2} e^{1 / 2} A \Delta H M(1 / z)
$$

式（14）から分かるように, 偏向信号のピーク高さは溶 媒相の光学的, 熱的性質を表すパラメーター $A$, 化学反 応熱 $\Delta H$ 及び反応物の量 $M$ と比例し, 一方プローブ光 の水/溶媒界面からの距離 $z$ と反比例することが明らか になった。

Fig. 6 には反応熱による偏向信号のピーク高さとプ ローブ光の界面からの距離との関係を示した. プローブ 光が界面に近いほぼ偏向信号が大きい, 一方, 滴下によ る界面のゆれにより生じたノイズも界面に近いほど大き い. 分光光度計用のセル $(1 \mathrm{~cm} \times 1 \mathrm{~cm} \times 5 \mathrm{~cm})$ を用い る場合, 界面から $1 \mathrm{~mm}$ 前後で最も大きな $S / N$ を得た.

又, 溶媒相を選択することにより, 溶媒相の光学的, 熱的性質を表すパラメーター $A$ の值が変わる. 式 (10) から分かるように, 屈折率の温度係数 $\mathrm{d} n / \mathrm{d} T$ が大きい 


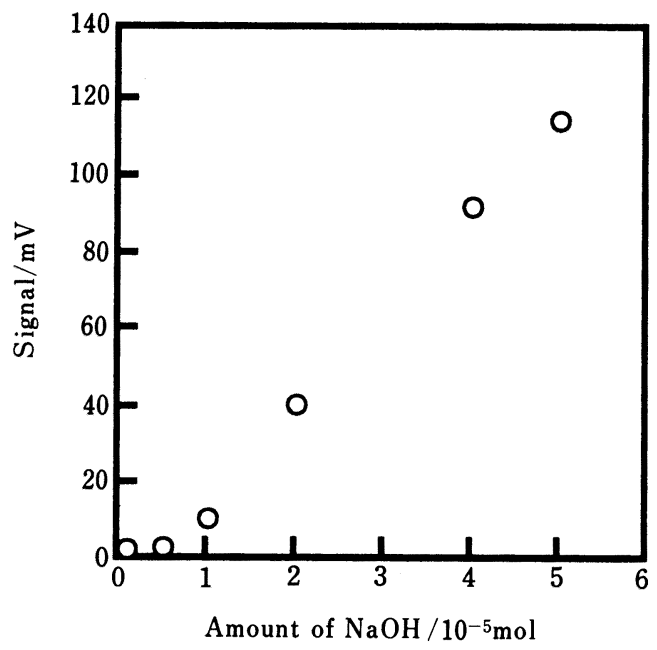

Fig. 7 Calibration curve of $\mathrm{NaOH}$ by reaction heat-induced beam deflection

ほぼ, 熱伝導率 $K_{2}$ 及び熱容量 $C_{2}$ が小さいほど, $A$ の 值が大きくなり，偏向信号も大きくなる．四塩化炭素は 有機溶媒の中で高い $\mathrm{d} n / \mathrm{d} T$ を持 5 , 又熱伝導率 $K_{2}$ 及 び熱容量 $C_{2}$ も小さく, この実験では好都合であるため これを選んだ。

偏向信号のピーク高さと反応した $\mathrm{NaOH}$ の量との関 係を Fig. 7 に示す. 偏向信号は反応物の量と直線関係 にあることが分かる．この定量関係は式 (14) からも分 かる. $\mathrm{NaOH}$ の定量下限は $5 \mu \mathrm{mol}(S / N=3)$ で, 定量 範囲は 5 50 $\mu \mathrm{mol}$ である. 計算から求めた反応熱の範 囲は $67 \sim 670 \mathrm{mcal}$ に相当する. $\mathrm{NaOH}$ の量が $50 \mu \mathrm{mol}$ を超えると偏向信号は大きくなりすぎ，プローブ光はす ベてナイフエッジにより遮断されてしまう。より良好な 位置検出器を使用すれば定量範囲は広げられる。

\section{$4 \cdot 2$ FIA の新規検出器としての応用}

次に,この手法をフローインジェクション分析 (FIA）の新規検出器として応用した ${ }^{25)}$. 著者らはまず マイクロスライドガラスで水/四塩化炭素界面を有する フローセルを設計，作製し，そのフローセルにあらかじ め $\mathrm{CCl}_{4}$ を入れておき，その上に $2 \mathrm{M} \mathrm{HCl}$ 溶液をペリ スタポンプで流し, $\mathrm{NaOH}$ 溶液を試料として $100 \mu \mathrm{l}$ 注 入した。. 結果として, 試作したフローセルは広い流量範 囲で安定なべースラインを与え，良好な $S / N$ が得られ た. 検出下限は $0.05 \mathrm{~mol} / \mathrm{l}(100 \mu \mathrm{l}$ 注入 $)$ で, 定量範囲 は $0.05 \sim 0.5 \mathrm{~mol} / 1$ であった. FIA に適用する場合, フ

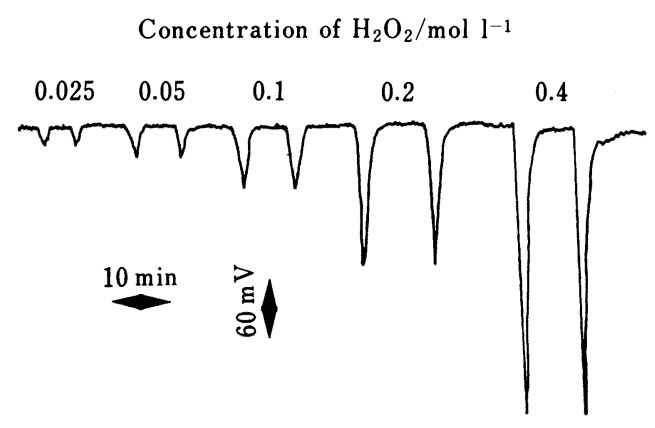

Fig. 8 Relationship between beam deflection signal and the concentration of $\mathrm{H}_{2} \mathrm{O}_{2}$ injected into flow cell

ローセル内の水 $/ \mathrm{CCl}_{4}$ 界面をいかに安定にするかが本測 定法の検出感度を左右する. フローセルについては, 後 述するような水相と $\mathrm{CCl}_{4}$ 相とを金ぱくで仕切る夕イプ

(Fig. 2, B) も考えられる.

\section{$4 \cdot 3$ 醭反応系への応用}

又, 本法を酔素反応系へも応用した。 カタラーゼによ る過酸化水素の分解反応をモデル醉素反応として用い た ${ }^{26)}$. まず, 酵素反応場を $\mathrm{CCl}_{4}$ 相上に置き, 反応を起 こさせた，この場合, 反応熱による偏向信号, 及び醅素 反応の生成物である $\mathrm{O}_{2}$ の $\mathrm{CCl}_{4}$ 相への溶解, 抎散によ り生じた濃度こう配による偏向信号が同時に検出され る ${ }^{26)}$. 反応熱による偏向信号に着目するため, Fig. 2, B に示したように，熱容量が小さい薄い金ぱく（厚さ 10 $\mu \mathrm{m} ）$ で反応セルの底を封じた，このセルの場合，水/四 塩化炭素界面の摇れにより生じたノイズが小さくなる.

偏向信号之過酸化水素の濃度及び酵素活性亡の定量関 係についてバッチ実験で検討したところ, 偏向信号は $\mathrm{H}_{2} \mathrm{O}_{2}$ の濃度及び酵素活性と直線関係にある. $\mathrm{H}_{2} \mathrm{O}_{2}$ の 定量範囲は $4 \times 10^{-3} \sim 4 \times 10^{-2} \mathrm{M}$ で, 検出下限は

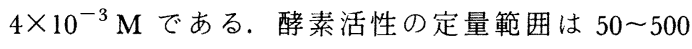
unit/ml である ${ }^{26)}$.

更に，金ぱく上に酵素カタラーゼをタンパク質血清ア ルブミンと架橋法で固定した ${ }^{27)}$.リン酸緩衝溶液を酵 素固定化したセルに連続的に流し，そこへ $\mathrm{H}_{2} \mathrm{O}_{2}$ 溶液 を $40 \mu \mathrm{l}$ 注入した (Fig. 2, B). 流量が $1.6 \mathrm{ml} / \mathrm{min}$ のと き, 偏向信号は $\mathrm{H}_{2} \mathrm{O}_{2}$ の濃度と $2.5 \times 10^{-2} \mathrm{M} \sim 5 \times 10^{-1}$ $\mathrm{M}$ の範囲内で直線関係を示した (Fig. 8). 検出下限は $2.5 \times 10^{-2} \mathrm{M}$ であった．この固定化酵素と結合した $\mathrm{H}_{2} \mathrm{O}_{2}$ の FIA 偏向測定法の安定性については, 13 時間 内 100 回の連続測定を行ったところ, 反応熱による偏 

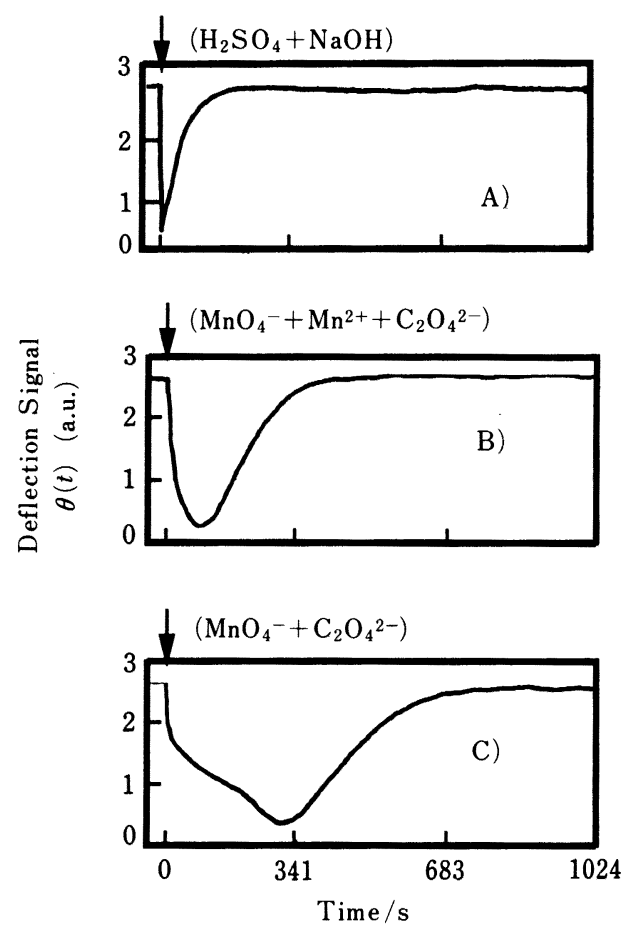

Fig. 9 Deflection signals for the neutralization reaction $(\mathrm{A})$ and the oxidation-reduction reactions in the presence (B) and absence of $\mathrm{Mn}^{2+}(\mathrm{C})$ in the reaction medium beforehand

向信号は全く変化しなかった ${ }^{27)}$. 更に, 固定化酵素の 活性は 2 週間内安定であることも確認した。これらの ことは本手法を固定化酵素と組み合わせ, 新規バイオセ ンサーとして利用できることを示唆している.

\section{4 反応速度の解析への応用}

次に本法による反応速度の解析について検討し $た^{28) 29)}$. この場合, $\mathrm{MnO}_{4}{ }^{-} \sim \mathrm{C}_{2} \mathrm{O}_{4}{ }^{2-}$ 酸化還元反応を モデル反応として用いた。

Fig. 9, A，B，C はそれぞれ中和反応系, 酸化還元系 (あらかじめ $\mathrm{Mn}^{2+}$ が存在する場合と存在しない場合) の偏向信号の時間変化を示す. 速い中和反応の場合, 反 応開始直後に偏向信号はすぐ最大になり,一方酸化還元 反応の場合, ある時間を経てから偏向信号が最大にな る.

理論で述べたように，遅い反応の偏向信号が式 (11) のように表され，熱源としてデル夕関数で扱えるような 瞬間的な反応の偏向信号と反応速度とのコンボリューシ

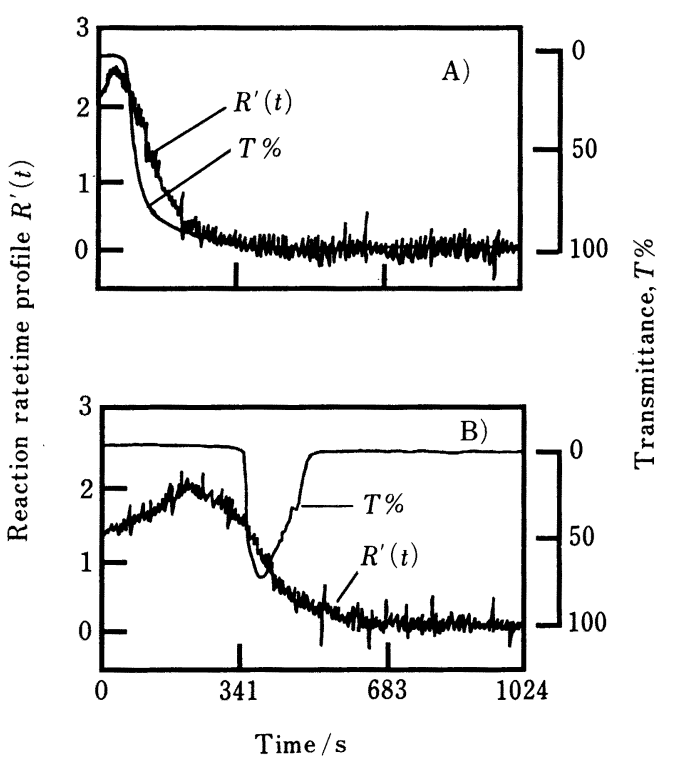

Fig. 10 Reaction rate decay curve $R^{\prime}(t)$ obtained by the deconvolutions of the deflection signals and transmittances of a $543 \mathrm{~nm}$ laser beam

A) in the presence of $\mathrm{Mn}^{2+}$ beforehand, B) in the absence of $\mathrm{Mn}^{2}$ beforehand

ヨンになる．従って, 遅い反応の反応速度がその反応系 の偏向信号と瞬間的な反応系の偏向信号からデコンボリ ユーションすることにより得られる．ここでは粗い近似 として, 中和反応を瞬間的な反応と仮定し, その偏向信 号 $\Delta \theta$ 及び酸化還元反応の偏向信号 $\Delta \Theta$ からデコンボ リューションした.デコンボリューションにより得た反 応速度に比例する $R^{\prime}(t)$ を Fig. 10 に示す. Fig. 10 か ら,この系で $\mathrm{Mn}^{2+}$ があらかじめ存在する場合と存在 しない場合, 酸化還元反応がそれぞれ 340 秒と 650 秒 前後で終了したことが明らかである。

一方, 反応速度が反応物の濃度の減少速度あるいは生 成物の濃度増加速度 $\mathrm{d} C / \mathrm{d} t$ で表される ${ }^{37)}$. 従って,この 系の反応速度が $\mathrm{MnO}_{4}^{-}$の濃度測定から解析できる. そこで, $\mathrm{MnO}_{4}{ }^{-}$(吸収極大波長 $535 \mathrm{~nm}$ ) が吸収を示す $543 \mathrm{~nm}$ の $\mathrm{He}-\mathrm{Ne} レ$ レ゙ービームを用い, その透過率 $T$ （\%)をモニターした. 本来, 透過率データ $T(\%)$ から 吸光度に変換し, その吸光度が $\mathrm{MnO}_{4}{ }^{-}$の濃度に比例 するので, 時間 $t$ に対して微分すれば，反応速度になる はずである. しかし, 本反応系での $\mathrm{MnO}_{4}{ }^{-}$の濃度が 高すぎて, 反応の初期段階で $543 \mathrm{~nm}$ の $\mathrm{He}-\mathrm{Ne} レ$ ザー光がすべて吸収され（透過率が 0 , 吸光度が無限 
大)，ベールの法則の適用範囲を超える。このため，こ こでは透過率デー夕を吸光度に変化せず，直接偏向信号 の解析結果と比較し, 討論を行う. 透過率測定結果も Fig. 10 に示す. Fig. 10, A から分かるように, $\mathrm{Mn}^{2+}$ があらかじめ存在するとき，透過率は 340 秒以後ほと んど変化しない。これはすべての $\mathrm{MnO}_{4}^{-}$が既に反応 したこと，つまり反応がすでに終わったことを意味して いる.これは偏向信号の解析結果と一致している. 反応 の初期段階での反応速度については，既に述べたように 透過率デー夕から解析できない，又，Fig. 10，Bにおい て透過率が途中から 0 になったのは，酸化還元反応の 生成物である $\mathrm{CO}_{2}$ の気泡がレーザビームに入ってに 机は目視で確認した)，光を散乱させたからである，従 って, 四光法あるいは透過法はこのような気泡や，沈殿 生成反応系の計測には利用できない，一方，本法ではこ のような問題がない.

\section{$4 \cdot 5$ 化学反応の一次元 in-situ 計測法の開発}

更に, 本法により化学反応の一次元計測についても検 討した ${ }^{30)}$. Fig. 11 には内径 $2.3 \mathrm{~mm}$ のガラス管内でモ デル反応としての中和反応を発生したときの, 反応熱に よる偏向信号の一次元イメージである. 反応開始直後, イメージセンサーの 375 番目のチャンネル前後から偏 向信号が測定され始める. 375 番目のチャンネル前後の 位置が反応セ儿の中心に対応する，又，反応開始から約 3, 4 秒後最大偏向信号が測定される. 偏向信号がイ メージ検出器の $375 \pm 50$ 番前後の範囲内で検出され, これは反応セル中心から $\pm 1.25 \mathrm{~mm}$ 内に対応する。一 方，反応セルとして使用されたガラス管の内径は 2.3 $\mathrm{mm}$ （半径 $1.15 \mathrm{~mm}$ ）である．偏向信号のイメージ範囲 と反応セルの大きさとの差は主に熱拡散によるものであ る. 又, この熱拡散が本法の空間分解能を左右すると考 えられる，現段階では，正確な空間分解能がまだ不明で あるが，この差を考慮すると約 $0.1 \mathrm{~mm}$ 程度であると考 えられる. 又, 偏向信号の大きさが反応物の量と比例す るので, ガラス管の直径方向が反応物の量が最も多いこ とも Fig. 11 に示されている. 従って, 全体として, ガ ラス管内での中和反応はよくイメージされたと考える. この手法が反応活性の分布測定に利用できるものと期待 できる。

\section{$4 \cdot 6$ 本手法の特徵及びこれからの課題と展望}

本手法の特徵: 以上, 本法が化学反応系における定量 分析, 反応速度の解析, 更に一次元空間内の分布情報の 解析に使用できることを明らかにした。本化学計測法は

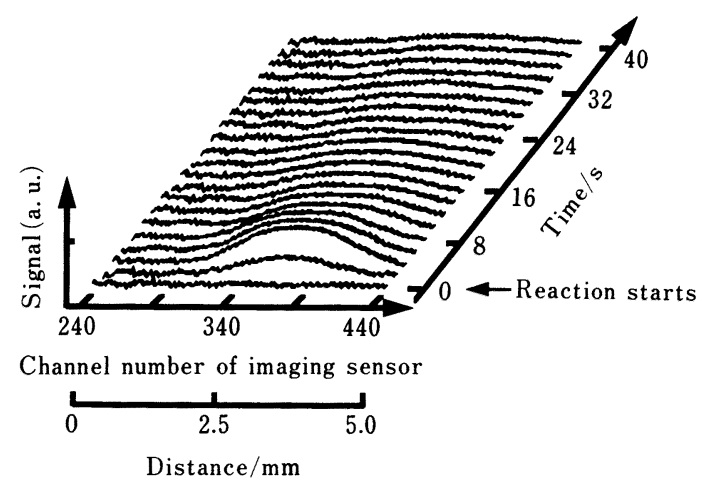

Fig. 11 Typical one dimensional reaction heat-induced beam deflection image for the neutralization reaction

反応熱によるビーム偏向効果に基づくものであり，新規 の熱測定法になるのであろう，従って，熱量測定法ある いはカロリメトリー以外の化学反応計測法と比較する と，すべての反応系に適用できるという特長がある．

一方，熱測定法あるいはカロリメトリーと比較する と, 本法が 4.5 節に述べたように, 化学反応の一次元 分布測定を簡単にできるという特長を有する（更に化学 反応の二次元，三次元分布への測定に応用できる可能性 もある). 又, 本法が化学反応系の in-situ 計測に適用で きるのに対し，従来のカロリメトリーでは測定対象物を 温度制御するので，in-situ 計測に適しない，現段階で本 法の満足できないところは測定感度が十分ではないこと である. 現在, 本法の反応物あるいは生成物の検出限界 は $\mu \mathrm{mol}$ あるいはサブ $\mu \mathrm{mol}$ レベルであり, 温度制御を 行う市販の熱量測定装置より低い，本法の測定感度の向 上が今後の一つの課題となる。

今後の課題と展望: 光熱偏向分光法での偏向信号の測 定は高感度で, $10^{-3 \circ} \mathrm{C}$ 程度のような微小な温度変化で も測定できる．これは光熱偏向分光法での偏向信号があ る周波数の交流信号なので，ロックインアンプによりそ の交流信号を検出するとき，その変調周波数と同一な周 波数のノイズ成分のみを拾う。従って，ノイズレベルは 低い，一方，反応熱によるプローブ光の偏光信号はある 特定の周波数の成分ではなく，多数の周波数成分の無限 和である。この場合，偏向信号に含まれるノイズも多数 の周波数成分の無限和であり，ノイズレベルは光熱偏向 分光法よりはるかに大きい。このため, 本法は温度制御 を行わない in-situ 測定でセル周辺の温度変化（通常 $0.1^{\circ} \mathrm{C}$ 程度）以下の反応熱による偏向信号の測定は困難 
である，現在, 検出感度の向上を図るため, 反応セルの 最適化, ノイズの周波数成分分析, ノイズの補正, 及び 反応熱による偏向信号の積算などについて検討してい る.

又, 反応熱によるプローブ光の偏向信号から, 反応熱 自体の測定については原理的には可能であるが, 式 (9) （11)に示すように反応速度や熱導電率, 屈折率 の温度変化係数などの物理化学定数の正確な測定が必要 とされる. 一方, 反応熱及び反応速度が既知のモデル反 応を参照反応として用いれば，未知反応の反応熱を求め ることも可能と考えられる。これも今後に残されたもう 一つの課題である.

本研究にあたって, 東京都立大学工学部工業化学科保母 敏行教授, 山田正昭, 内山一美両助教授加終始貴重な指 導と助言をいただきました。ここで深く感謝致します。又, 本研究は文部省の科研費助成 (課題番号 0870000 , 05855120，06650936）を受けたことを付記し, 感謝の意を 表します。

\section{文献}

1) A. Velasco, M. Silva, D. Perez: Anal. Chem., 64, 2359 (1992).

2) X.-Z.Wu, T. Kitamori, T. Sawada: J. Phys. Chem., 96, 9402 (1992).

3) A. K. Campbell: "Chemiluminescence: Principles and Applications in Biology and Medicine", (1988), (Horwood, Chichester)

4) X.-Z. Wu, M. Yamada, T. Hobo, S. Suzuki: Anal. Chem., 61, 1505 (1989).

5) D. Betteridge, M. T. Joslin, T. Liley: Anal. Chem., 53, 1064 (1981).

6) T. Sawada, C. Abe, Y. Goshi, K. Furuya: Anal. Chem., 57, 366 (1985).

7) W. Wendlandt: "Thermal Methods of Analysis", 3d ed., (1986), (Wiley, New York).

8）藤枝修子：ぶんせき (Bunseki), 1993, 615.

9) M. J. Muehlbauer, E. J. Guilbeau, B. J. Towe: Anal. Chem., 61, 77 (1989).

10) A. C. Boccara, D. Fournier, J. Badoz: Appl. Phys. Lett., 36 (2), 130 (1980).

11) L. C. Aamodt, J. C. Murphy: J. Appl. Phys., 52, 4903 (1981).

12) J. C. Murphy, L. C. Aamodt: J. Appl. Phys., 51, $4580(1980)$.

13) N. J. Dovichi: CRC Crit. Rev. Anal. Chem., 17, 357 (1987).
14) T. Kitamori, T. Sawada: Spectrochim. Acta Rev., 14 (4), 275 (1991).

15) J. Wu, T. Kitamori, T. Sawada: Anal. Chem., 63, 217 (1991).

16) J. Wu, T. Kitamori, T. Sawada: Anal. Chem., 62, 1676 (1990).

17) J. Pawliszyn: Spectrochim. Acta Rev., 13 (4), 311 (1990).

18) J. Pawliszyn, Michael F. W., M. J. Dignam, R. D. Venter, Su-M. Park: Anal. Chem., 58, 236 (1986).

19) J. Pawliszyn, Michael F. W., M. J. Dignam, R. D. Venter, Su-M. Park: Anal. Chem., 58, 239 (1986).

20) J. Pawliszyn: Anal. Chem., 64, 1552 (1992).

21) L. R. Lima, R. E. Synovec: Anal. Chem., 65, 128 (1993).

22) C. N. Renn, R. E. Synovec: Anal. Chem., 62, 558 (1990).

23) G. Chen, E. S. Yeung: Anal. Chem., 60, 864 (1988).

24) X.-Z. Wu, H. Shindoh, M. Yamada, T. Hobo: Anal. Chem., 65, 834 (1993)

25) X.-Z. Wu, H. Shindoh, M. Yamada, E. Kobayashi, T. Hobo: Anal. Sci., 10, 203 (1994).

26) X.-Z. Wu, H. Shindoh, T. Hobo: Microchem. J., 49, 213 (1994).

27) X.-Z. Wu, H. Shindoh, T. Hobo: Anal. Chim. Acta, 299, 333 (1994).

28) X.-Z. Wu, H. Shindoh, T. Hobo: Anal. Chim. Acta, in press.

29）吳 行正, 保母敏行, 北森武彦, 澤田嗣郎：熱測 定, 22, 143 (1995).

30) X.-Z. Wu, K. Uchiyama, T.Hobo: Anal. Lett., submitted.

31) H. S. Carslaw, J. C. Jaegew: "Conduction of Heat in Solid", (1959), (Oxford Uni. Press, London).

32) J. N. Demas, G. A. Grosby: Anal. Chem., 42, 1010 (1970).

33) S. S. Brody: Rev. Sci. Instrum., 28, 1021 (1957).

34) W. R. W. Lewis, L. J. Doemeny, L. J. Nemzek: Rev. Sci. Instrum., 44, 107 (1973).

35) X.-Z. Wu, J. Wu, J. Pawliszyn: J. Electrophoresis, 16, 1474 (1995).

36) P. W. Carr, L. D. Bower: "Chemical Analysis, Vol. 56: Immobilized Enzymes in Analytical and Clinical Chemistry", (1980), (Wiley Interscience, New York).

37) G. M. Barrow: "Physical Chemistry", 4th ed., (1979), (International Student Edition, Tokyo). 


\section{要旨}

反応熱によるプローブ光の偏向を利用する新規 in-situ 化学計測法の原理，装置系の作製，及び応用 について詳しく検討した．まず，反応熱によるプローブ光の偏向信号の理論式を導出した．次に中和反 応をモデル反応として用い，その偏向信号の実測データと計算値とを比較した．又，その他の測定条件 の基礎的な検討も併せて行った．更に，本法が定量分析，フローインジェクション分析の検出器に使用 できることと，酵素反応系，酸化還元反応系へ応用できることを明らかにした．本法による反応速度の 解析, 化学反応系の一次元空間分布情報の解析が可能であることも示した. 本法の課題及び今後の展開 についても述べた。 